原著

\title{
左中・下側頭回後部病変により顕著な漢字書字障害を 呈した症例の言語訓練経過
}

\author{
鶴田 薰 ${ }^{1)}$ 福迫 陽子 $^{21}$ 河村 満3) 物井 寿子'
}

要 約 : 左中・下側頭回後部病変に伴い重度の漢字書字障害を呈した症例について発症初期 からの言語症状を詳細に分析し,その後長期間にわたり言語訓練を行った結果を報告した。症例 は 62 歳, 女性, 右利き, 脳出血. 発症後 1 力月の MRI では左中・下側頭回後部皮質, 皮質下白質 に高信号域が認められた。他の言語機能はほぼ保たれていたのに比し, 漢字の自発書字・書取が 重度に障害されていた。小学校 1.2 年生学習漠字の書取検査では, (1)正答率は $24.4 \%$ に過ぎな い, (2)画数増加に伴い正答率が低下する, (3)誤り方は「目標文字に関係のない誤り」が最も多く, 中でも「部分反応」新作文字」の率が高い,などが認められた。なお書けない漢字でも意味理解, 正答字の選択はほぼ可能であった. 15 力月間, 書字訓練を行ったところ, (1)正答率の改善 (73.3 \%), (2)画数増加に伴い正答率が低下する傾向の減少, (3「目標文字に関係のない誤り」の激減, (4) 未訓練文字への般化率が低いままであること,などが得られた。

索引用語 : 漢字書字障害, 左中・下側頭回後部病変, 誤り分析, 言語訓練, 経過

\section{Recovery Process of a Patient with Severe Deficit in Writing of Kanji Characters due to Lesions of the Left Posterior Part of the Middle and Inferior Temporal Gyrus - a case report-}

Kaoru Tsuruta ${ }^{1)}$, Yoko Fukusako ${ }^{2)}$, Mitsuru Kawamura ${ }^{3)}$ and Hisako Monoi ${ }^{11}$

\begin{abstract}
This is a case report on a patient who suffered severe deficit in writing of kanji characters resulting from a cerebrovascular accident. The patient was a 62 -year-old right-handed woman with cerebral hemorrhage who showed severe deficit in writing of kanji characters both spontaneously and under dictation. The findings of MRI revealed lesions in the left posterior part of the middle and inferior temporal cortex and white matter. The results of a dictation test of 221 kanji characters that are learned in the lst and 2nd grades of elementary school were as follows : (1) the number of totally correct answers
\end{abstract}

1) 東京都老人医療センター言語聴覚科： $\bar{T} 173$ 東京都板橋区栄町 35-2

2) 東京大学医学部音声言語医学研究施設 : $=113$ 東京都文京区本郷 7-3-1

3) 千葉大学医学部神経内科：干 280 千葉市亥鼻 1-8-1

1) Speech Pathology Service, Tokyo Metropolitan Geriatric Hospital : 35-2 Sakae-cho, Itabashi-ku, Tokyo 173

2) Research Institute of Logopedics and Phoniatrics, Faculty of Medicine, University of Tokyo : 7-3-1 Hongo, Bunkyo-ku, Tokyo 113

3) Department of Neurology, Faculty of Medicine, University of Chiba : 1-8-1, Inohana, Chiba 280 原稿受理：1991 年 7 月 2 日 
was only $54(24.4 \%)$; (2) the percentage of correct answers decreased with the number of strokes in the kanji ; and (3) the error type observed most frequently was "error irrelevant to target character", of which "partial response" and "neologic character" were evident in particular. In addition, regarding the kanji characters she was unable to write correctly, the patient showed capability to discriminate visually between correct ones and false ones, as well as to understand their meaning. Training in kanji writing was administered mainly using a copying method from 2 to 17 months post onset. Through a 15-month treatment, the following findings were obtained : (1) the number of totally correct answers rose to 162 (73.3\%) ; (2) the tendency toward difficulty relating to number of strokes declined ; (3) the number of "errors irrelevant to target character" decreased greatly ; and (4) treatment efficacy extending to untrained characters remained low.

Key words : Deficit in kanji writing, lesions of the left posterior part of the middle and inferior temporal gyrus, error analysis, language therapy, recovery process

\section{I.はじめに}

1891 年の Dejerine ${ }^{1)}$ 報告以来, 失読失書は左角回 病変で生ずることが定説になっている.しかし, 1982 年, 山鳥 ${ }^{2)}$ は失読失書例 5 例中 1 例 (症例 K.N.) の病変 部位は, X線 CT により左角回ではなく「左第 2 ・第 3 側頭回後方から後頭葉移行部にかけての深部」であっ たと報告した。この症例の症状は, 漢字より仮名が重度 の失読と, 漢字・仮名双方の失書であった.一方, $\operatorname{Iwata}^{3)}(1984)$, 岩田 ${ }^{4)}(1988)$ は, 山鳥 ${ }^{2)}$ の症例 K.N.とほ ほ同じ病変部位 (脳出血発症後 6 週目のX線 CT にて, 「左中〜下側頭回後端部の皮質〜皮質下に低吸収域」) を有する症例において, 発症後 3 力月の時点では失語 を伴わず「ほとんど漢字のみの失読失書」を呈した症例 を報告した。岩田 ${ }^{4)}$ はこの病変部位を左側頭葉後下部 と呼び,この領域が「漢字語の読み書きにおいて重要な 役割を果している」との考えを提起した。Iwata ${ }^{3)}$ の報 告以後, 同部位病変に伴う読み書き障害が注目され, 現 在までの報告数は右手利き左病変に限れば 20 例を数 え ${ }^{5 \sim 20}$. 20 例の原因疾患は, 脳血管障害 19 例(梗塞 8 例, 出血 10 例, 出血性梗塞 1 例), および頭部外傷 1 例であった.脳血管障害 19 例の病変部位(全例 X 線 CT か MRIによる) は全例左側頭葉後下部であるが, これに加えて, 後頭葉を含むもの 7 例, 後頭葉その他を 含む多発性 1 例であった。

山鳥 ${ }^{2)}$, Iwata $^{3)}$ の症例を含めた 22 例の症状は, 失読 失書 13 例, 漢字の純粋失書 4 例, 漢字の失読失書 2 例, 漢字に強い失読失書 1 例, 仮名の純粋失読と漢字の失 読失書 1 例, 純粋失読と漢字の失書 1 例であり,一致し た見解は得られていない。

漢字書字障害の転帰が記載されている 13 例中, 3 例
で自然回復がみられたが, 10 例では漢字書字障害が残 存した。なお,これまで漢字の書字訓練を特に取り上げ て検討した報告はみあたらない。

われわれは, 上記報告例と同様の左中・下側頭回後部 の病変に伴い, 重度の漢字書字障害をきたした症例を 経験した。本例について発症初期から症状を詳細に分 析し, 長期間にわたり言語訓練を行ったので, 書字障害 の特徴と訓練効果について報告する.

\section{II. 症例}

発症時年齢 62 歳, 女性, 病院雑務員, 右利き, 教育歴 9 年.今回発症前は簡単なメモ, 手紙などは漢字も用い て可能であった。

既往歴：59 歳 (1986 年) 頃から高血圧のため投薬治 療中であった。 62 歳時の 1989 年 1 月 25 日, 高血圧性 脳内出血により軽度の左片麻舫を来し東京都老人医療 センターに入院した. 保存的療法により軽快し, 同年 2 月 9 日に退院した。

現病歴：1989 年 4 月 17 日朝, 朝刊を読もうとした ところ新聞の文字はみえてはいるが意味が分からない こと,子供や孫の名前は呼べるが漢字で書けないこと に気付いた。 4 月 19 日, 東京都老人医療センター脳神 経外科を受診し脳出血と診断された.さらに失読失書, 失名詞失語, 失計算が指摘され即日入院となった。

\section{1 .初回評価時の状態}

神経学的所見 : 入院時は意識清明で, 運動麻瘒, 感覚 障害, 視野障害は認められず, 腱反射にも異常を認めな かった。また麻痺性構音障害, 嚥下障害も認められなか つた.

神経放射線学的所見：発症後 1 力月の MRI ・ T 1 強 調画像 (図 1 ) では, 左中側頭回後部から左下側頭回後 


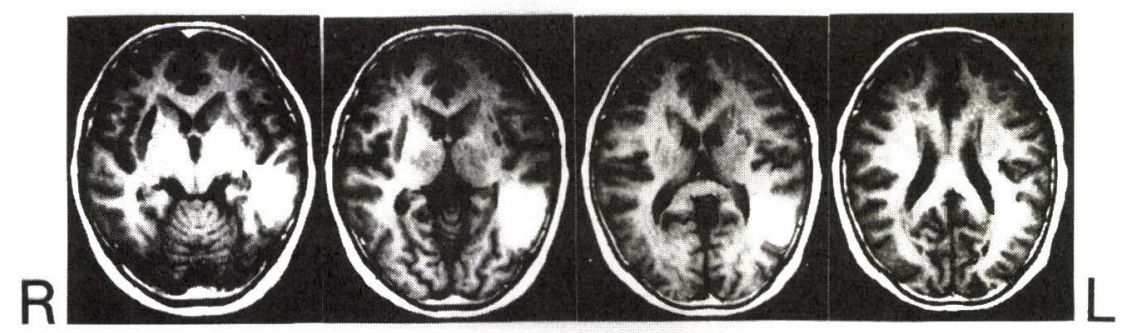

図 1 MRI（発症後 1 力月)

部にかけての皮質・皮質下白質に限局性の高信号域が みられた.また右被殼に縦に長い低信号域が認められ た.

神経心理学的所見(発症後 16 日～1 月月)：頭頂葉 検査(ボストンテスト ${ }^{21)}$ より), 高次脳機能検査(老研 版 $)^{22)}$, および当センター言語恥覚科で用いている失行 失認スクリーニング検査により見当識, 左右の認知, 手 指の認知, 顔の認知, 色名想起・理解, ぬり絵, 2,3 次元 構成, 数字の記憶にはいずれも障害は認められなかっ た.ただし,物語の直後再生は 7 語で健常者の $89.5 \%$, 遅延再生は 3 語で健常者の $47.6 \%$ と低下が認められ た.計算については, 発症後 2 日には 100 から 7 を引く 暗算や 1 桁同士の加算の暗算に誤りが認められたが, 発症後 16 日にはこのような䛊りは認められなくなつ た. 失語症鑑別診断検査 (老研版) (以下 DD 検査と略 す)の筆算では加算は可能であったが, 桁数が増加した 場合に減算・乗算・除算は䛊りが認められた.九九は可 能であった.知的な側面はWAIS にて動作性 IQ86, 言 語性 IQ82, 全 IQ82 であったが, 患者の背景を考慮する とほほ正常レベルと考えられた。

\section{言語病理学的所見:}

(1) 言語機能: DD 検査の)総得点は307/379(81.0 \%)であった.聞く面については, 単語の聴認知, 短文・ 長文の理解に䛊りは認められなかったが,「指示に従 う」は 10 問中 6 割正答であった. 聴覚的把持力は単語 4 単位 (土), 数詞(順) 5 単位 (土), 数詞(逆) 5 単位 (土) であり, 正常レベル,トークンテストは 142 点(正答率 $86.1 \%$, 以下「正答率」は略す)で, 実用レベルであっ た.

話す面については, 発話は流暢で, 文を用いて意思を 伝達することが可能であった.100 単語呼称検査では 66 語正答(ただし語頭音の手がかりを与えると 90 語 正答)であり,誤り方は無反応がほとんどであった。語 想起は語頭音 18 語/ 4 分, カテゴリー19 語/4 分と軽

\begin{tabular}{|c|c|c|}
\hline 本 & 無反応 & 玉人 \\
\hline 山 & $L^{\prime}$ & やま \\
\hline 犬 & 無反応 & $\because \not 2$ \\
\hline 足 & 足 & あし \\
\hline H & $\eta$ & मे \\
\hline 電話 & $\pi 0^{\circ}$ & でんわ \\
\hline 手袋 & 手 & てぶく3 \\
\hline 時計 & 。時訫 & とH川 \\
\hline 鉛筆 & 無反応 & えんて゚フ \\
\hline 靴下 & 总高 & 〈つた \\
\hline 退題) & (漢字自発書字) & (仮名自発書字) \\
\hline
\end{tabular}

図2 DD 検査「漢字単語自発書字」 と「仮名単語自発書字」(発 症後 1 力月 右手使用)

度低下が認められた。復唱は 10 問中 6 割, 6 文節程度 の文まで可能であった。

文字の読解は漢字, 仮名単語の視・聴認知, 短文の理 解, 長文の理解, すべて正答であった.「指示に従う」は 10 問中 5 割の正答にとどまったが, 誤りは物品名の取 り違えによるものがほとんどであった.音読は DD 検 
廿の子がでんわをがけている

おかあさんがあみすのとしてます

おとうさんがたばこをのみながりてれでをみている

男の子がしんぶんをとつてきれた

水厂が双て詰

ギきヤうがはいつてす

図 $3 \mathrm{DD}$ 検查「情景画叙述」（発症後 1 力月 所要 時間 3 分 40 秒)

査では漢字単語, 仮名単語, 短文ともすべて正答であ り, 反応は素早かった. 音読の掘り下げ検査のうち, 漢 字単語は 60 問中 58 個正答 $(97.0 \%)$, 平仮名 1 文字は 104 問中 102 個正答 $(98.0 \%)$, 平仮名単語·片仮名単語 は 72 問すべて正答であった.長文は, 発症後 16 日に実 施した「北風と太陽」の音読所要時間は 2 分と健常者の 約 3 倍を要し, 誤りも認められたが, 発症後 1 力月には 1 分 6 秒で誤りは認められなくなった。

書く面については, まず写字は左右手とも漢字, 仮名 いずれも一瞥した後ただちに書き始め,書き終わるま での速度は速かった。単語の自発書字, 書取において仮 名は 10 問すべて正答であるにも関わらず, 漢字の正答 は $2 \sim 3$ 割であり, 漢字の成績が際立って低かった(図 2 ).長文の作文 (DD 検査「情景画の叙述」)では図 3 の ように仮名を多用したが, 喚語や構文の能力はほほ保 たれていた。なお，本人・家族によると書体は病前と変 わらないとのことであった。

(2) 漢字書字障害に関する精査所見; 小学校 1.2 年 生学習漢字 221 字 (昭和 52 年告示の文部省「学習指導 要領」より)について書取検査(目標漢字を単一にいつ てもわかりにくい場合はこれを含む熟語や句を聞か
せ,目標漢字のみを書き取らせた)を行ったところ,正 答数は 54 個,正答率は $24.4 \%$ であった. 図 4 は正答率 と画数との関係を検討したものである.横軸は画数と それに該当する漢字数,縌軸は正答率を示している.こ れから,画数が増加するに伴い正答率が低下する傾向 が認められた。なお正答率と漢字の具体性, 熟知度 (北 尾ら ${ }^{23)}$ による)との間には関係は認められなかった。次 に誤った文字 167 個の誤り方を目標文字との関係の有 無によって分析した(表 1).なお誤り方の分類には長 谷川ら ${ }^{24)}$ の方法を参考にした。その結果,「目標文字に 関係のない誤り」が 75 個, $45.0 \%$ と最も多く,次いで 「無反応」53 個, $31.7 \%$,「目標文字に関係のある誤り」 39 個, $23.3 \%$ \%゙り, 3 つの誤り方の間には統計的に 有意差が認められた(カイ自乗検定 $5 \%$ 水準).最も誤 り頻度が高い「目標文字に関係のない誤り」の中でも 「部分反応 $\rfloor 25$ 個 (15.0\%), 「新作文字 $\rfloor 23$ 個 (13.8\%), の 2 つ率が高かった.なお, 漢字の自発書字・書取で は仮名と異なり,書字開始までに時間を要し,書き終え るのも遅かった。また誤りに気付きながらも自己修正 は困難であった.しかし,正答字を選択肢から選ぶこと は可能であった。

以上まとめると, 発症直後は失名詞失語と読み書き 障害が認められたが, 初回評価時の発症後 1 力月には 読み障害と仮名の書字障害は軽度となり, 失名詞失語 と漢字の顕著な書字障害が残った。

\section{2.書字訓練}

訓練内容：訓練目的は,音声言語は会話レベルでほ ほ実用的であるのに対し漢字の書字が顕著に障害され ていること,および患者の漢字訓練に対する意欲も高 いことから, 漢字書字能力の向上とした。具体的には小 学校 1.2 年生学習漢字のうち初回検査時に正答でなか つた漢字 167 字を書字可能とすることとした。訓練期 間は 1989 年 6 月から 1990 年 9 月までの 15 カ月間で,

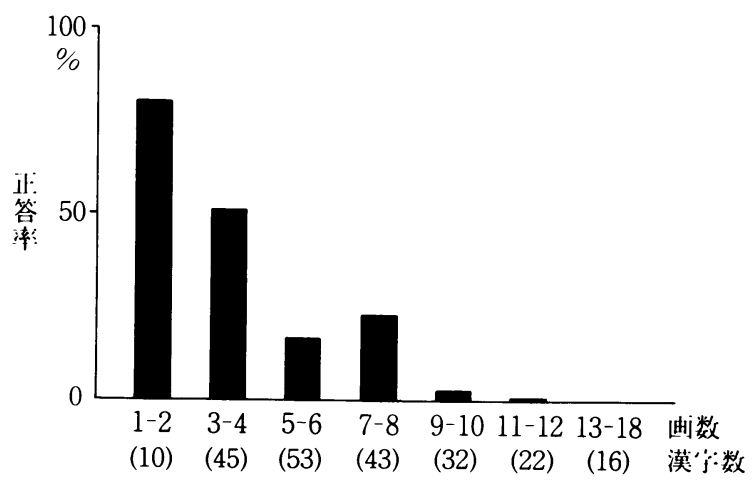

図 4 小学校 $1 \cdot 2$ 年生学習漢字 221 字の画数別書 取成績（発症後 1 力月） 
表 1 誤り反応の分析

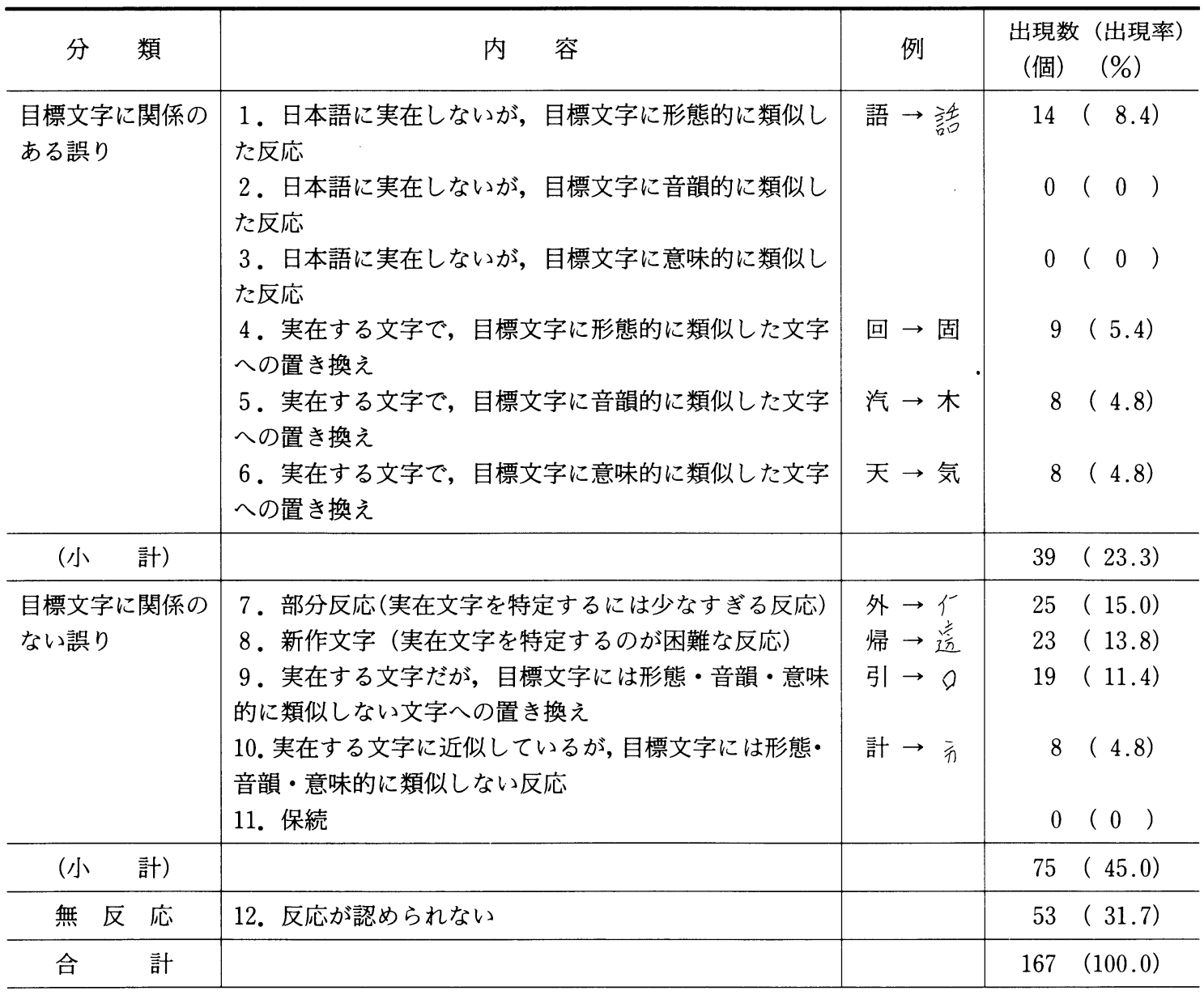

2 期に分かれ,第 I 期は 1989 年 6 月から同年 9 月まで の 4 力月間(訓練回数は週 $2 \sim 4$ 回) ( 1 年生学習漢字 30 字),第II期は 1989 年 10 月から 1990 年 9 月までの 11 力月間(訓練回数は週 2 回) ( 2 年生学習漢字 137 字)であった.訓練方法は, 写字が完全であることを利 用し, 訓練対象漢字を宿題として 10 回以上模写させ, 訓練室ではこれを書取らせた。漢字が想起できない場 合は, 訓練者が目標漢字を構成する部首名や部分を口 頭で説明し(例“早” $\rightarrow\lceil$ 日曜日の日」と「数字の十」), こ れらの手がかりを書き取らせて文字を完成させる方法 を試みた.しかし,初期には手がかりそのものが想起で きないことが多かったため, 漢字の部首や書き出しの 部分を訓練者が書いて示す必要があった。なお,訓練対 象漢字の選択は偏や旁,画数を考慮して試みても学習 の効果にさほど違いが認められなかったため, 50 音順 とした.訓練対象漢字は 10 文字を 1 グループとして取 り上げ, 次の 10 文字に移る基準は $100 \%$ 書取可能とな
った時点とした。これに要する訓練回数は $8 \sim 12$ 回程 度であった。この傾向は訓練が終了に近づいた時期に おいても同様であり,訓練が進むにつれて学習期間が 大幅に短縮されることは認められなかった。

\section{3 .検査成績の推移}

図 5 は, 小学校 1.2 年生学習漢字書取検査正答率の 推移である.初回時の正答率は $24.4 \%$ であったが, 発 症後 6 力月には $47.1 \%$, 発症後 12 力月には $67.4 \%$ と 順調に伸びた。発症後 17 力月の訓練終了時には 73.3 \%と初回検査時に比し, $49.3 \%$ の改善が認められた. 初回時には顕著であった画数増加に従い正答率が低下 する傾向は, 発症後 6 力月には著しく隇少し,その後も 訓練が進むにつれて軽減した(図 6 ).発症後 17 力月に は, 11 画以上の漢字の正答率は低いものの, 10 画以下 の漢字の正答率の間には統計的な差は認められなくな った(カイ自乗検定 $5 \%$ 水準).

図 7 は,誤り方の推移をみたものである.出現率と経 


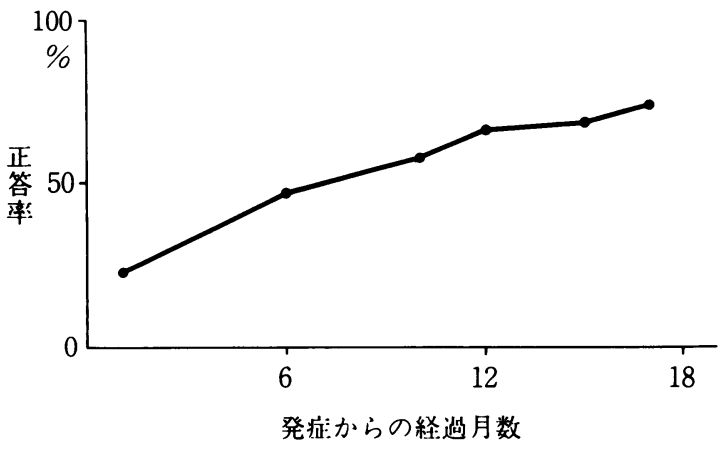

図 5 小学校 $1 \cdot 2$ 年生学習漢字 221 字の書取成績 の推移

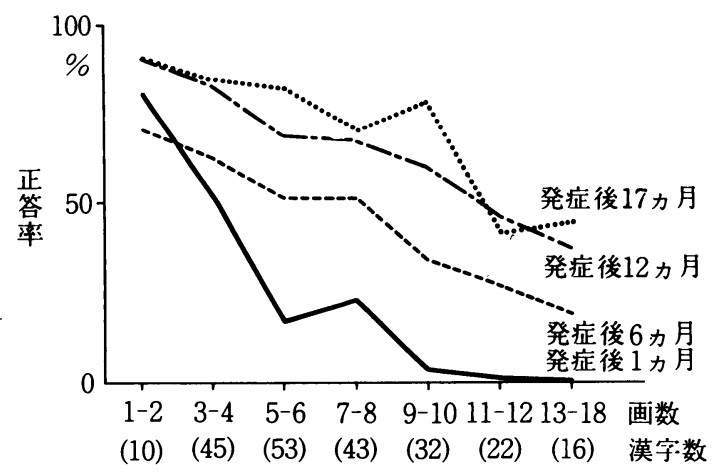

図 6 小学校 1 - 2 年生学習漢字 221 字の画数別書 取成績の推移
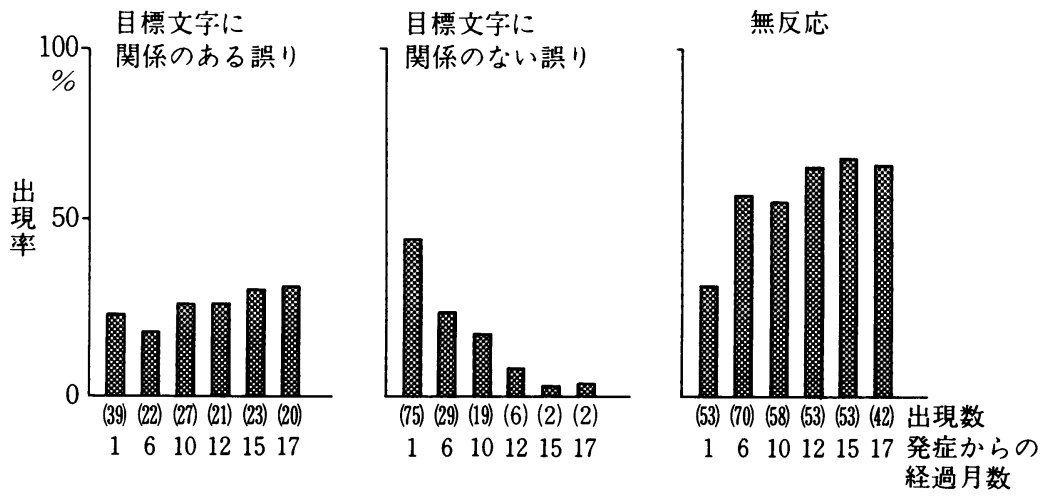

図 7 誤り方の推移

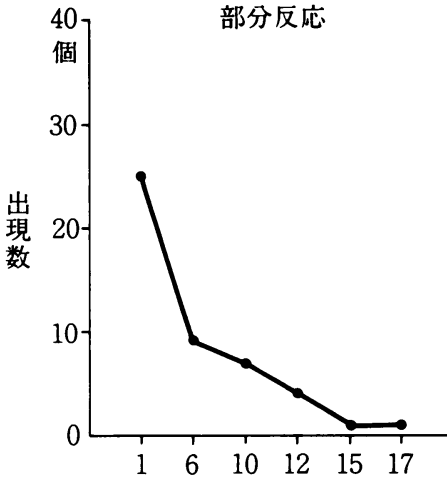

発症からの経過月数

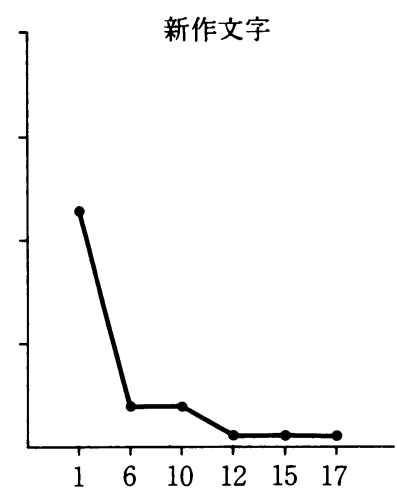

発症からの経過月数

図 8 部分反応・新作文字の出現数推移

過の間に最も関連が深いのは,「目標文字に関係のない 誤り」であった.すなわち発症後 1 力月における出現率 は $45.0 \%$ \%あったが,経過とともに次第に減少し,発 症後 17 カ月には $3.1 \%$ となった。一方, 「目標文字に関 係のある棓り」の出現率は経過を通じて 20〜30\%の範 囲であった。「無反応」の出現率は初回時には $31.7 \%$ \%て
あったが発症後 6 カ月には $57.9 \%$, 発症後 12 カ月に は $66.3 \%$ と増し,以後は発症後 17 力の訓練終了時 まで同程度であった。図 8 は「目標文字に関係のない誤 り」のうち初期に俱り率が高かった「部分反応」と「新作 文字」について出現数の経過をみたものである.まず, 「部分反応」出現数は初回時の 23 個から, 発症後 6 力月 
に 9 個, 発症後 15 力月には 1 個, また「新作文字」出現 数は初回時 23 個が発症後 6 力月に 4 個, 発症後 12 力 月には 1 個と,おのおの激減した。

図 9 は初回評価時に正答でなかった漢字のうち,訓 練を全く行わなかったにもかかわらず書けるようにな つた漢字の正答率の発症後 10 力月以降における推移 である.なお,一定期間経過後の正答率は訓練したこと による波及効果,つまり訓練の般化と考えられるので, 以下般化率と呼ぶことにする。般化率は, 経過を通じて $9.1 \%$ から $19.1 \%$ の範囲にとどまり,統計的に有意差 は認められなかった.すなわち漢字書取成績が経過に 伴い改善したにも関わらず,般化率には上昇は認めら れなかった。

図 10 は発症後 17 力月(訓練終了時)における $\mathrm{DD}$ 検 查「情景画の叙述」である.仮名の多用は減少し,必要な 漢字はほぼ書けていた。

\section{III. 考 察}

\section{1. 本例における漢字書字障害の診断}

本例は, 発症直後には失読失書と失名詞失語が認め られたものの, 発症後 1 力月頃までには, 顕著な漢字書 字障害と軽度の失名詞失語を呈するのみとなった。本 例における書字障害はどのような性質のものと考える べきであろうか.

書字障害を呈する診断カテゴリーとしては一般に, 失語症に伴う失書, 全般的精神活動低下に伴う失書, 失 読失書, 純粋失書, 脳梁損傷による離断性失書, 右半球 病巣による空間性失書, 構成失書, があげられるが, 本 例では, X線 CT および MRI の所見から離断性失書, 空間性失書は否定された。また,構成失書の可能性は文 字の構成および写字に問題はないことから除外され た,したがって本例で問題となるのは失語症に伴う失 書, 全般的精神活動低下に伴う書字障害, 失読失書, 純 粋失書である.失語症に伴う失書については, 本例では 漢字書字を除くと言語の各側面の障害は, 軽度で日常 生活上ほとんど支障が認められなかったのに対し, 漢 字の自発書字, 書取の障害が特異的に重篤であったこ とから否定された.全般的な精神活動低下に伴う書字 障害の有無については, 発症後の日常生活上の言動は 病前と変わらず,病識も保たれていること,および各種 心理検查成績において正常範囲であったことから否定 された。純粋失書については, 本例は失読にて発症に気 づかれており,また発症後 1 力月以内では軽度ではあ るが漢字・仮名双方に読みの障害が認められたため, これには該当しなかった。

したがって, 本例の漢字の書字障害は, X線 CT およ

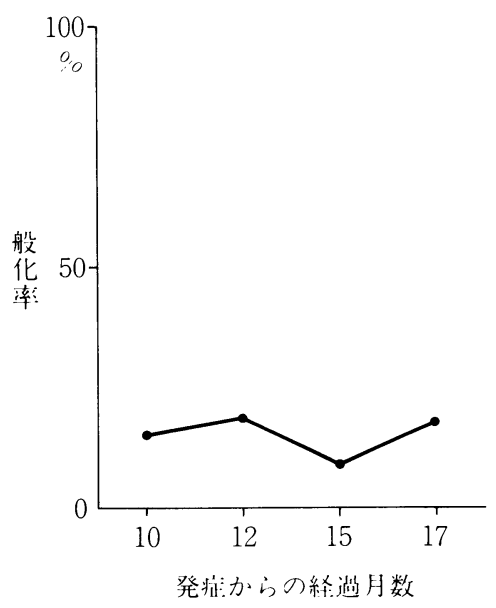

図 9 般化率の推移

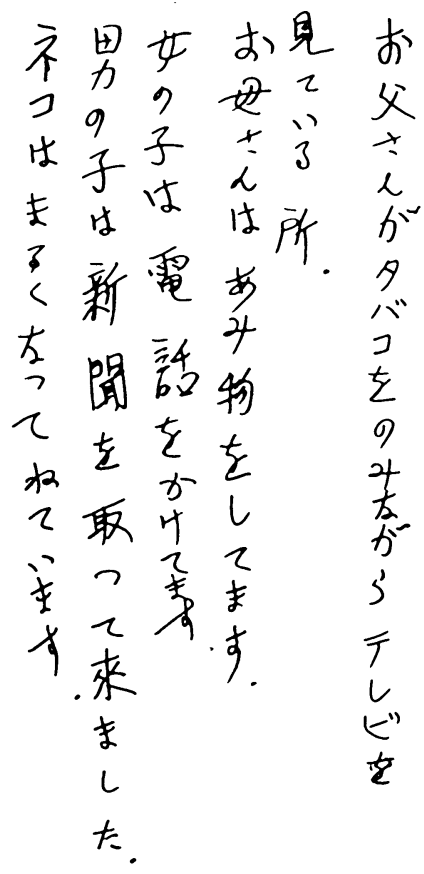

図 10 DD 検査「情景画叙述」 (発症後 17 力月 所要 時間 5 分)

びMRI で得られた病変部位から,近年報告が集積さ れてきた, 左中・下側頭回後部病変に伴う読み書き障害 の範疇に該当し, 発症初期の失読失書が経過に伴い漢 字の書字障害に変化したものと判断された。なお,本例 では左中・下側頭回後部病変に伴う読み書き障害に失 名詞失語を伴ったが, 同様の症例は表 2 でみるように 従来の報告例においても珍しくなく, 22 例中 16 例に 認められている. 


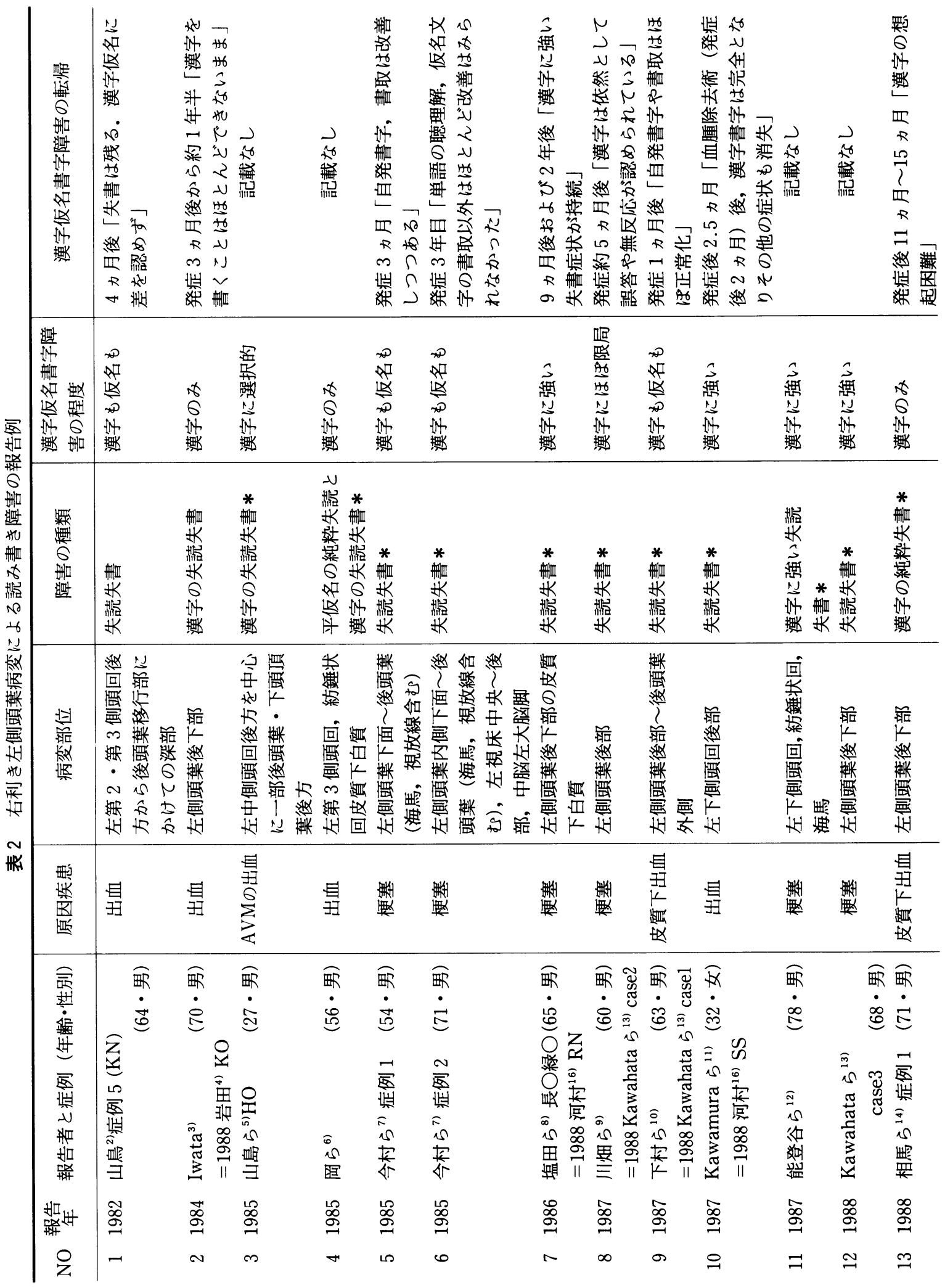




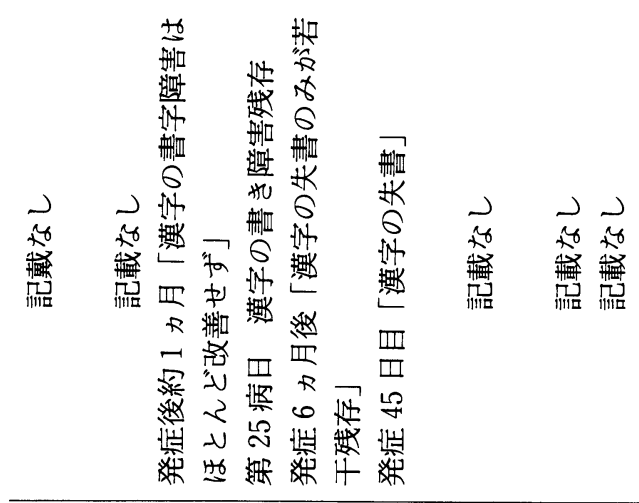

\begin{tabular}{|c|c|c|c|c|c|}
\hline 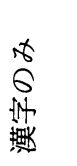 & 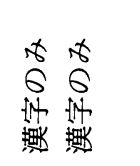 & 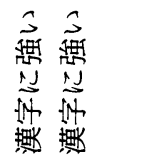 & 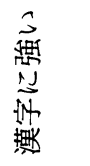 & 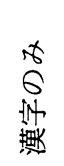 & 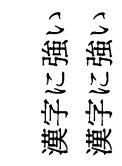 \\
\hline 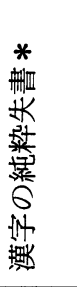 & 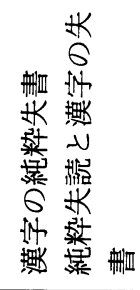 & 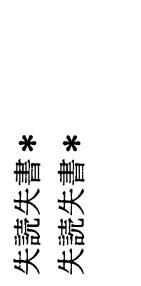 & 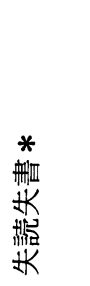 & 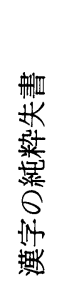 & 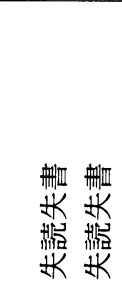 \\
\hline 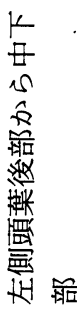 & 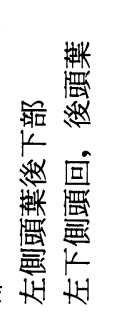 & 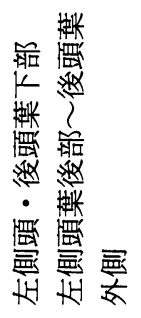 & 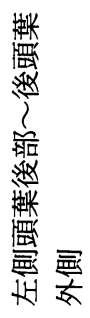 & 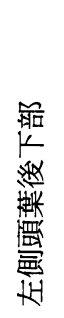 & 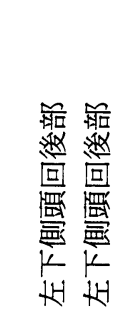 \\
\hline 䛧 & 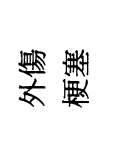 & 䀒目 & 貝 & 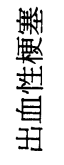 & 萛萛 \\
\hline $\begin{array}{l}\overparen{\not x} \\
\dot{\infty} \\
\stackrel{0}{0}\end{array}$ & 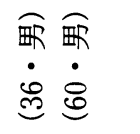 & $\begin{array}{l}\text { 畍 } \\
\dot{x} \\
\dot{0} \\
\dot{0}\end{array}$ & $\begin{array}{l}\text { 两 } \\
\dot{\hat{0}}\end{array}$ & 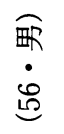 & 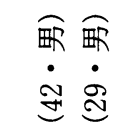 \\
\hline 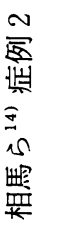 & 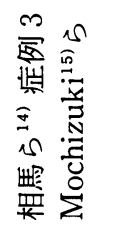 & 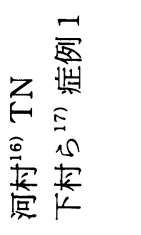 & 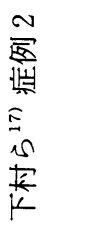 & $\begin{array}{l}0 \\
\infty \\
0 \\
0 \\
\tilde{0} \\
0 \\
0 \\
0 \\
0\end{array}$ & 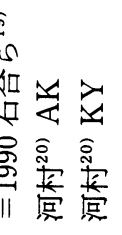 \\
\hline $\begin{array}{l}\infty \\
\infty \\
\stackrel{-}{-1}\end{array}$ & $\begin{array}{ll}\infty & \infty \\
\infty & \infty \\
\infty & \infty \\
\end{array}$ & 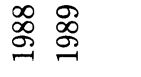 & $\begin{array}{l}\stackrel{2}{\circ} \\
\stackrel{-}{9}\end{array}$ & ஓ & ஓ ஓ ஓ \\
\hline- & $\stackrel{2}{\longrightarrow} \mathscr{-}$ & $\simeq \stackrel{\infty}{=}$ & $\stackrel{9}{-1}$ & ฉి & $\vec{\sim} \approx$ \\
\hline
\end{tabular}

本例の書字障害の特徵は, 写字は左右手ともに漢字, 平仮名, 片仮名のいずれにおいても問題がなく,また, 平仮名, 片仮名の自発書字・書取はほほ保たれているに も関わらず, 漢字の自発書字・書取のみ重度に障害され ていることであった。従来の報告例(表 2 )を書字につ いてみると, 漢字の障害が仮名に比べ重篤であるとす るものは 22 例中 18 例と多い. 漢字障害の重症度は, 従 来の報告では患者自身の氏名にも錯書が認められた 例 $^{8)}$ から, 検查対象文字数の 9 割以上の書取が可能で あった例 ${ }^{11}$ まで幅がある.本例では, 発症初期におい て, 住所の書字が困難であったこと, 発症後 1 力月の時 点で小学校 1.2 年生の漢字書取検査の成績が $24.4 \%$ と低かったことから, 重度と判定された。

なお,右手で書かせた場合と左手で書かせた場合の 成績の間には, Yokota ら ${ }^{18)}$ の症例と同様に本例でも 差は認められなかった,

\section{2.初回評価時の漢字書字障害の特徵}

まず, 本例では, 漢字の画数が多くなる,すなわち形 態が複雑になるに従い, 正答率が低下する傾向が認め られたが, 同様のことは, 相馬ら ${ }^{14)}$, Yokota $~^{18)}$, 石合 ら ${ }^{19)}$ の報告でも認められている。漢字の具体性および 熟知度との関係については今回初めて検討を加えた が, 関係は認められなかった。

次に, 本例の漢字の誤り方については, まず無反応は 誤り反応全体の約 3 割を占め, 従来の報告例, ${ }^{4,17,19}$ に 比べると少なかった。誤り文字による反応で特徵的で あったのは「目標文字に関係のない誤り」が最も多いこ とで,この中でも「部分反応」,「新作文字」が主であるこ と,「目標文字に関係のある誤り」の中でも音韻的, 意味 的誤りよりも形態的誤りが多いことから,誤った文字 形態を想起する傾向が初回時は強かったことが示され た.従来の報告例においても, 漢字の誤り方では, 新作 文字が認められる ${ }^{12)}$, 部分反応が認められる ${ }^{5,14)}$, 形態 的な誤りがある゙', ことが指摘されている.また本例で は,誤字を自覚していても訂正できないが正答は選択 可能であること, 漢字の読解には問題がなく, 書取すべ き語の意味は理解されていること, 自発書字・書取に比 し写字は容易であることから, 漢字の辞書項目は基本 的にはほほ保存されていることが推測された.したが って本例の書字障害は漢字形態の想起障害に起因する ものと推測され, 岩田 ${ }^{4)}$ が指摘した「目標漢字図形の視 覚的想起に問題があること」を裏付ける症例と考えら れた。

最後に, 本例の漢字書字障害の症状が左中・下側頭回 後部病変による特異な症状であるか否かについて, 頭 頂葉性純粋失書症例との比較において述べたい.本例 
の書字障害と,本邦における頭頂葉性純粋失書 6 例 $^{20,25)}$ との共通点としては, (1)自発書字, 書取ともに障 害がある, (2)写字に障害がみられない, (3)障害は右手で 書いても左手で書いても変わらない,があげられる.さ らに頭頂葉性純粋失書においても漢字・仮名双方に障 害があるとは必ずしも限らず,顕著な漢字障害を示す 例がある ( 6 例中 1 例) こと, 漢字の誤り方を分析した 5 例中 4 例で「無反応」の割合が $2 \sim 6$ 割を占めること が指摘されている.一方, 両者間で異なる点としては, 「新作文字」の出現率が, 本例は $13.8 \%$ あるのに対 し, 頭頂葉性純粋失書は全例 0 〜 $5 \%$ と低いことがあ げられる.また,「実在する他の文字への置き換え」が本 例では $26.4 \%$ (表 1 中の項目 $4,5,6,9$ の合計) であ るのに対し, 頭頂葉性純粋失書は $15 \%$ 以下と低いこと も特徵的である.なお, 頭頂葉性純粋失書について漢字 の正答率と画数との関係に言及した報告は見当たらな かった. 以上から判断すると, 本例と頭頂葉性純粋失書 例の症状にはかなりの類似部分があるものの, 漢字書 字の誤り反応分析の結果には異なる点もあるというこ とができる。

\section{3 .経過と訓練}

本例では発症後 1 力月から 17 力月にわたる集中的 な書字訓練の結果, 顕著な改善が認められた. 表 2 にみ るように, 従来の経過報告例 13 例 (全例, 訓練は行って いない) 中, 漢字書字障害が改善または正常となった 3 例はいずれも発症後 3 力月未満に改善を認めている. これに対し, 改善が認められなかった 10 例中 7 例の経 過期間は, 3 力月以上 2 年以内である.なお, 年齢, 病変 の範囲, 原因疾患などについては一定の傾向はみいだ しがたい.以上から 13 例という限られた症例数ではあ るが, 改善が起きた症例は, 全例発症後 3 力月末満であ ることから, 自然治癒の期間は発症後 3 力月未満とい う仮説が成り立つと考えたい.この仮説については,な お今後の検討が必要であるが,これが正しいとすれば, 本例でみられた初期の改善には自然治瘭によるものも 加わっている可能性がある.すなわち, 発症後 6 力月 に, 画数増加に伴い正答率が低下する傾向が目立たな くなったこと,および「目標文字に関係のない誤り」の うち「部分反応」「新作文字」の出現数が初回時に比し激 減したことは, 自然治癒の存在を示唆するものかもし れない.しかしながら, 少なくとも第 2 回評価(発症後 6 力月)以降に認められた改善, すなわち正答率が増加 し続けたこと, 画数増加に伴い正答率が低下する傾向 が目立たなくなったこと,「新作文字」「部分反応」の出 現数がさらに低下したこと,などは訓練効果とみなし て良いであろう.本例は書字訓練について検討した初
めての症例であることから,今回の結果は, 左中・下側 頭回後部病変に伴う漢字書字障害患者の中には言語訓 練が有効な例が存在することを示す証拠となろう.

一方, 本例では訓練を行わない文字における般化率 は,訓練が進んだ段階においても低い状態にとどまっ たこと, 漢字を学習するのに要する期間は訓練の初期 と終了時との間でほとんど差が認められなかったこ と,を考慮に入れると, 訓練効果は得られたものの訓練 の波及効果は低かったといわざるを得ない.もしも本 例で訓練を実施しなかったとすれば, 既報告例にある ように,おそらく重度の漢字書字障害が残存したであ ろうと推測される。

なお,本例における訓練効果の維持については今後 の検討が必要である。

本研究の一部は第 35 回日本音声言語医学会総会 (1990 年 10 月 徳島)において発表した。

本研究にご協力下さった東京都老人医療センター言語聴覚科 の皆様に謝意を表する.

\section{文献}

1) Dejerine, J. : Sur un cas de cécité verbale avec agraphie, suivi d'autopsie. C.R. Soc. Biol., 3 : 197 $\sim 200,1891$.

2) 山鳥 重: 失読失書と角回病変. 失語症研究, 2 : 236 242, 1982.

3) Iwata, M. : Kanji versus Kana. Neuropsychological correlates of the Japanese writing system. Trends Neurosci., $7: 290 \sim 293,1984$.

4) 岩田 誠：左側頭葉後下部と漢字の読み書き.失 語症研究, $8: 146 \sim 152,1988$.

5）山鳥 重,元村直靖, 遠藤美岐,三谷洋子：範疇特 異性失読と読字過程の神経心理モデル.失語症研 究, $5: 817 \sim 821,1985$.

6）岡 尚省,浅野次義,服部 進,持尾聰一郎, 杉下守 弘：左第三側頭回および紡鍾状回損傷により生じ た純粋失読と失読失書. 神経内科, $23: 73 \sim 76$, 1985 .

7）今村重洋,大野訓正, 中嶋斐子,山永裕明,出田 透：優位側側頭・後頭葉病変に基づく失読失書の 2 例. 神経内科, $23: 362 \sim 368,1985$.

8）塩田純一, 河村 満, 磯野 理, 平山恵造：左側頭 葉後下部限局性梗塞病変による失読失書.脳神経, $38: 1051 \sim 1055,1986$.

9）川畑信也, 田川皓一, 平田 温,長田 乾, 宍戸文 男：左側頭葉後下部の脳梗塞により出現した失読 
失書の 1 例. 臨床神経, $27 ： 420 \sim 427,1987$.

10）下村辰雄, 田川皓一, 長田 乾, 宍戸文男, : 左側頭 葉後部から後頭葉外側部の皮質下出血による失読 失書の 1 例. 神経内科, $26: 57 \sim 64,1987$.

11) Kawamura, M., Hirayama, K., Hasegawa, K., Takahashi, N., Yamaura, A. : Alexia with agraphia of kanji (Japanese morphograms). J. Neurol. Neurosurg. Psychiatry, $50: 1125 \sim 1129$, 1987.

12）能登谷晶子,鈴木重忠, 倉知正佳, 小山善子, 平松 博：左下側頭葉損傷による失読一失書の一例. 神 経心理学, $3: 244 \sim 250,1987$.

13) Kawahata, N., Nagata, K. : Alexia with agraphia due to the left posterior inferior temporal lobe lesion-neuropsychological analysis and Its pathogenetic mechanisms. Brain Lang., 33 : 296〜310, 1988.

14）相馬芳明, 杉下守弘, 丸山勝一, 喜多村孝一, 椿 忠 雄 : 側頭葉後下部損傷による「漢字の純粋失書」. 神経内科, $29: 172 \sim 178,1988$.

15) Mochizuki, H., Ohtomo, R. : Pure alexia in Japanese and agraphia without alexia in kanji. arch. Neurol., 45 : 1157 1159, 1988.

16）河村 満：非古典型純粋失読. 失語症研究, 8 : 185 193, 1988.

17）下村辰雄,鈴木孝輝, 高橋 暁：左側頭葉後下部を 中心とする皮質下出血による失読失書の 2 例. 神 経内科, $30 ： 396 \sim 403,1989$.

18) Yokota, T., Ishiai, S., Furukawa, T., Tsukago- shi, H. : Pure agraphia of kanji due to thrombosis of the Labbé vein. J. Neurol. Neurosurg. Psychiatry, $53:$ 335 338, 1990.

19）石合純夫, 横田隆徳, 古川哲雄, 塚越 廣, 杉下守 弘：側頭葉後下部損傷による漢字の失書のメカニ ズムーアイカメラによる写字過程の検討一. 失語 症研究, $10 ： 259 \sim 264,1990$ 。

20）河村 満：純粋失読-純粋失書・失読失書の病態. 神経心理学, $6: 16 \sim 24,1990$.

21）笹沼澄子,物井寿子：失語症の評価,医学書院, 1975.

22）笹沼澄子,伊藤元信, 綿森淑子, 福沢一吉, 佐久間尚 子, 福迫陽子, 物井寿子：痴呆の神経心理学的研究 一障害構造の検索一. 神経心理学, $3: 216 \sim 225$, 1987.

23）北尾倫彦, 八田武志, 石田雅人, 馬場園陽一, 近藤淑 子：教育漢字 881 字の具体性, 象形性および熟知 性. 心理学研究, $48 ： 105 \sim 111,1977$.

24）長谷川啓子, 河村 満：頭頂葉性純粋失書の書字 障害の分析 -2 症例での検討.聴能言語学研究. $6: 28 \sim 34,1989$.

25）河村 満, 平山恵造, 長谷川啓子, 館野之男, 宍戸文 男, 杉下守弘：頭頂葉性純粋失書一病変と症候の 検討一. 失語症研究, $4: 656 \sim 663,1984$.

\section{別刷請求先： $\bar{\top} 173$ 東京都板橋区栄町 35-2} 東京都老人医療センター言語聴覚科 鶴田 薫 